\title{
Advances in stem cell therapy for cardiovascular disease (Review)
}

\author{
RONGRONG SUN, XIANCHI LI, MIN LIU, YI ZENG, SHUANG CHEN and PEYING ZHANG \\ Xuzhou Central Hospital, The Affiliated Xuzhou Hospital of Medical College \\ of Southest University, Xuzhou, Jiangsu 221009, P.R. China
}

Received November 9, 2015; Accepted April 28, 2016

DOI: $10.3892 /$ ijmm.2016.2607

\begin{abstract}
Cardiovascular disease constitutes the primary cause of mortality and morbidity worldwide, and represents a group of disorders associated with the loss of cardiac function. Despite considerable advances in the understanding of the pathologic mechanisms of the disease, the majority of the currently available therapies remain at best palliative, since the problem of cardiac tissue loss has not yet been addressed. Indeed, few therapeutic approaches offer direct tissue repair and regeneration, whereas the majority of treatment options aim to limit scar formation and adverse remodeling, while improving myocardial function. Of all the existing therapeutic approaches, the problem of cardiac tissue loss is addressed uniquely by heart transplantation. Nevertheless, alternative options, particularly stem cell therapy, has emerged as a novel and promising approach. This approach involves the transplantation of healthy and functional cells to promote the renewal of damaged cells and repair injured tissue. Bone marrow precursor cells were the first cell type used in clinical studies, and subsequently, preclinical and clinical investigations have been extended to the use of various populations of stem cells. This review addresses the present state of research as regards stem cell therapy for cardiovascular disease.
\end{abstract}

\section{Contents}

1. Introduction

2. Spectrum of stem cells investigated

3. Modes of stem cell delivery

4. Potential therapeutic mechanisms of stem cells

5. Conclusion

Correspondence to: Dr Peying Zhang, Xuzhou Central Hospital, The Affiliated Xuzhou Hospital of Medical College of Southest University, Xuzhou, Jiangsu 221009, P.R. China

E-mail: zpying58@126.com

Key words: stem cells, cardiovascular disorder, cardiac regeneration

\section{Introduction}

Cardiovascular disease refers to a group of diseases that affect the heart and blood vessels and contributes to approximately $30 \%$ of global mortality, making it the most contributory cause of mortality worldwide. Although the events leading to cardiovasucular disorders are multi-faceted, a fundamental problem is the presence of scar tissue, and the irreversible loss of cardiomyocytes, which dynamically contribute to the contractility and the relaxation of ventricles. This can eventually predispose to ventricular arrhythmias and lead to heart failure (HF).

Traditional therapeutic options employ a strategy to limit further scar formation and adverse remodeling (1), but do not address the problem of cardiomyocyte loss which can only be treated by heart transplantation. In view of the palliative rather curative effect of these treatments, new alternative therapies have been explored for over a decade, including gene, protein and stem cell therapies. In particular, stem cell therapy has become a new focal point for the treatment of cardiovascular disorders. The demonstration that bone marrow-derived mononuclear cells (BMMNCs) can repair myocardial damage and improve heart function by favoring myocardial regeneration or reduction of ventricular remodelling has generated great expectations (2). This discovery has transformed experimental research in the field of regenerative cardiovascular medicine and considerably increased the clinical investigation. Herein, we present an overview on advances in stem cell therapy for cardiovascular disease. Specifically, in this review, we address the present state of research as regards different stem cells that may be used to regenerate the myocardium, their modes of delivery and their mechanisms of action.

\section{Spectrum of stem cells investigated}

Since the first study reported in 1998 indicating the ability of skeletal muscle to repair the heart (3), various cell types illustrated in Fig. 1, have been investigated as possible candidates for treatment of cardiovascular disease.

Skeletal myoblasts (SMs). Given that SMs are believed to have sufficient plasticity to give rise to cardiac muscle, specimens of SMs obtained from muscle biopsies were originally used for cardiac regeneration (3). Advantageously, these cells have the ability to derive autologous cells, thus eliminating the need for immunosupression $(4,5)$. In addition, SMs have a high 


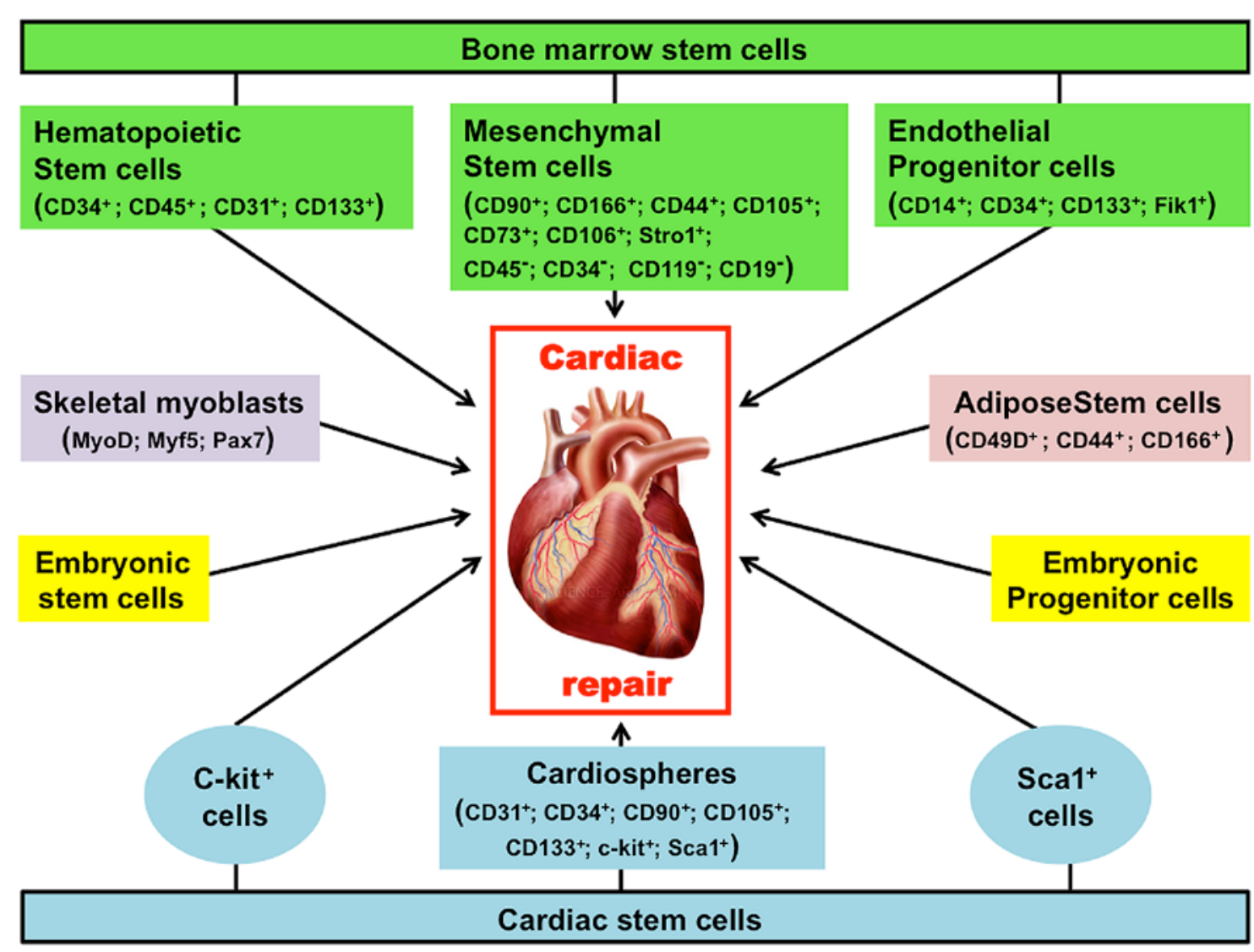

Figure 1. Spectrum of stem cells investigated for cardiac repair. Although the pathologic events leading to injured heart are multi-faceted, an underlying cause is a diminished blood supply to parts of the myocardium as a result of an occlusion to coronary artery. This translates into low, or no oxygen supply to the cardiac muscle leading to wide apoptosis and necrosis of the cells. As consequence, the heart cannot pump blood effectively to the rest of the body, thus leading to heart failure and ultimately death of the patient. The main purpose of stem cell therapies is the prevention and or regeneration of dying muscle. A variety of cell types have been investigated as candidates for such treatment. These cells include skeletal myoblasts, whole bone marrow cells or bone marrow-derived HSCs, bone marrow-derived MSCs, adipose-derived stem cells, adult cardiac resident stem cells, and ESCs including their differentiated progeny. The surface marker phenotypes that distinguish certain different stem cells are given in parentheses. HSCs, hematopoietic stem cells; MSCs, mesenchymal stem cells; ESCs, embryonic stem cells.

proliferative ability at a later stage of differentiation and are resistant to ischemia (3-5). Preclinical and clinical studies have revealed that SMs could differentiate into myotubes and form skeletal muscle-like grafts that are viable and functional in the damaged portions of myocardium. These changes were accompanied by a reduction in adverse ventricular remodelling and interstitial fibrosis as well as increased cardiac function (3-7). However, the inability of these implanted skeletal muscle cells to differentiate into cardiomyocytes (6), and to form electrical junctions (6) has raised potential concerns as regards the risk of ventricular tachycardia, and waned interest in their use for treatment of cardiovascular disease.

Bone marrow-derived stem cells. Bone marrow harbors several types of stem cells that include mesenchymal and hematopoietic stem cells (HSCs) that have been largely tested for their use in tissue/organ regeneration in several preclinical and clinical studies. These cells are easily procurable and also include unfractionated mononuclear cells, and endothelial progenitor cells (EPCs).

BMMNCs. In several animal models of acute myocardial infarction (AMI), BMMNCs have been used $(2,8)$ and were found to contribute to the regeneration of cardiomyocytes and endothelial cells following injection into infarcted myocardium.

The first clinical trial of BMMNCs in AMI, carried out in 2002 by Strauer et al (9), revealed that these cells improved global and regional ventricular function and enhanced myocardial perfusion. Similar results were obtained more recently in two separate trials of BMMNCs in AMI $(10,11)$. However, a double-blind investigation of BMMNC transplantation in the placebo-controlled LateTIME trial, at 2-3 weeks after myocardial infarction (MI) revealed no improvement in regional or global cardiac function (12). Furthermore, although the analysis of cohort studies and randomized clinical trials has shown a modest benefit in favor of BMMNCs in the treatment of patients suffering from left ventricular (LV) dysfunction post-MI, neutral result from other studies of autologous BMMNCs continue to fuel controversy about the clinical role of this potential new therapeutic tool.

Mesenchymal stem cells (MSCs). MSCs are non-hematopoietic cells that have the potential to differentiate into a variety of cell types. They have initially been identified in bone marrow, but are also found in umbilical cord blood, adipose tissue, and the heart. Importantly, MSCs from bone marrow do not express costimulatory molecules of the T-cell activation 
such as HLA class II and B7, allowing them to survive even under inflammatory conditions without interacting with host $\mathrm{T}$ cells. The use of these cells in rodent models of MI resulted in improvement of remodeling and reduction of infarct size following their differentiation into cardiomyocyte and endothelial phenotypes (13). Similarly, intracoronary infusion of autologous bone marrow-derived MSCs given to patients after MI resulted in improved LV function and myocardial perfusion (14). In the setting of $\mathrm{HF}$, infusion of autologous or allogeneic MSCs improved ventricular remodeling as well as the functional capacity, and quality of life of patient (15).

HSCs and EPCs. HSCs present in the bone marrow have the potential to differentiate into myeloid as well as lymphoid cell lineages. Whereas, EPCs are found in peripheral blood and they can differentiate into endothelial cells to promote neovascularisation in response to ischemic injury. CD34 and CD133 are surface markers of both HSCs and EPCs.

A sustained improvement in regional perfusion and LV remodeling by intracoronary cell therapy with both $\mathrm{CD} 133^{+}$ or $\mathrm{CD}_{34}{ }^{+}$cell types could be observed in old anterior $\mathrm{MI}$ patients (16). Interestingly, injection of $\mathrm{CD} 34^{+}$cells into the peri-infarct during coronary artery bypass grafting (CABG) surgery in patients with ischemic cardiomyopathy led to better improvement of contractile function as compared to CABG alone (17). Similarly, left ventricular ejection fraction (LVEF) and perfusion of the infarcted myocardium were found to be much improved in ischemic HF patients who received CABG and $\mathrm{CD}_{133^{+}}$therapy in contrast to patients treated only with CABG (18). The use of a novel population of hematopoietic cells, known as aldehyde dehydrogenase-bright $\left(\mathrm{ALDH}{ }^{\mathrm{br}}\right)$ cells, resulted in reduced LV end-systolic volume and an improvement of maximal oxygen consumption (19).

Adipose-derived MSCs. Miyahara et al were the first investigators to practice transplantation of adipose-derived MSCs into scarred myocardium in a rat model of chronic MI, and reported that this intervention led to better cardiac function, which was associated with reversal of wall thinning in the scar area (20). A subsequent comparative study demonstrated that MSCs not only help in improving LVEF, but they also promote angiogenesis and lower fibrosis and this ability of MSCs is better than adipose-derived cardiomyogenic cells or BMMNCs (21). However, the application of adipose-derived MSCs in the clinical setting for cardiovascular disease is still under evaluation.

Cardiac stem cells (CSCs). It is now known that there is a continuous turnover of cellular components of adult heart and this is an important development in our understanding of cardiac tissue biology. In as much as this process of cardiac cellular turnover is likely to be dependent on the population of stem cells present in the heart, several cardiac-derived stem cells have been evaluated as potential therapeutic tools.

$c-k i t^{+}$CSCs. The c-kit ${ }^{+}$CSCs refer to a multipotent cell population expressing the tyrosine kinase receptor c-kit, and are considered as a primary source for generation of a new myocardium subsequent to injury. The ability of these c-kit ${ }^{+}$ CSCs to curtail LV dysfunction and vascular remodeling, and also to promote cardiac tissue regeneration was consistently demonstrated in animal models of AMI (22-24). Clinical and preclinical studies have suggested that the intracoronary infusion of autologous c-kit ${ }^{+} \mathrm{CSC}$ results in the restoration of LV systolic function, and reduces infarct size in patients with cardiovascular disease due to ischemia (25).

Cardiosphere-derived cells (CDCs). CDCs are composed of various cell types that include cells expressing antigenic markers that are charactersitic of endothelial cells [KDR (human)/Flk-1 (mouse), CD3], stem cells (CD34, c-kit, Sca-1), and MSCs (CD105, CD90). These cells are able to promote regeneration, and to reduce both post-MI dysfunction and vascular remodeling in various animal models of MI (26-28); however, the specific cells responsible for these effects have not yet been identified. Nevertheless, considering that $98 \%$ of CDCs infused are found to be positive for CDC105, it has been suggested that the stem cell type responsible for this restoration is likely mesenchymal in nature (26). However, therapy with CDCs does not lead to a reduction in LV volume, an increase in LVEF, and an improvement in quality of life. Nevertheless, therapy with CDCs has been shown to lead to a $42 \%$ reduction in scar size along with an increase in viable tissue and regional systolic wall thickening in the infarcted region, which suggests cardiac regeneration (26).

Sca- $\mathrm{I}^{+} \mathrm{CSCs}$. Oh et al (29) originally reported the presence of Sca- $1^{+}$cells in the adult mouse heart, and demonstrated that these cells express cardiac structural genes, and differentiate into beating cardiomyocytes when treated with 5-azacydine or oxytocin. These authors also demonstrated that Sca- $1^{+}$cells, when transplanted into the peri-infarct and infarct zones in an animal model of MI, differentiated into endothelial cells and cardiomyocytes, and attenuated LV remodeling.

Embryonic stem cells (ESCs). ESCs are considered to be promising therapeutic candidate stem cells, since they are able to self-renew in an unlimited manner and can differentiate into any cell type of the organism, including cardiomyocytes. Accordingly, under appropriate culture conditions, human ESCs form contracting areas (30) and embryoid bodies, which are positive for cardiomyocyte markers such as myosin heavy chain, $\alpha$-actin, desmin and tropin I. The main advantage of ESCs is their capacity of unlimited expansion in vitro, allowing them to meet the need for large amounts of cells for transplantation. The administration of ESCs in an animal model of MI has been shown to result in engraftment, improved LV function and reduced LV remodeling (31). The disadvantages of ESCs are their propensity toward teratoma formation, and malignant transformation.

Induced pluripotent stem cells (iPSCs). Adult human somatic cells (32) and mouse fibroblasts (33), reprogrammed to pluripotent stem cells by transduction of transcription factors, were shown to differentiate into cardiomyocytes which possess functional properties typical of cardiac cells. Although these iPSCs are potential therapeutic candidates for cardiac regeneration, the transcription factors used for their generation such as cMyc, Oct4 and Klf4 are known oncogenes that can produce teratomas. In addition, iPSCs have a very low efficiency for generation and this varies among different batches of iPSCs, rendering their ability unpredictable (34). The rapidly evolving technology in this field may overcome these problems and the iPSC-based 
therapeutic approach could find applications in the treatment of cardiovascular disease.

\section{Modes of stem cell delivery}

The transplantation of sufficient numbers of cells into the myocardial region of interest and the achievement of maximum retention of cells within the area represent the primary objective of any cell delivery strategy. Current delivery strategies are transvascular approaches, and direct injection into the LV wall.

Transvascular approaches. The transvascular strategies are particularly appropriate for recent infarcted and reperfused myocardium when expression of chemo-attractants and cell adhesion molecules is prominent. These strategies include intracoronary delivery, intravenous infusion, and mobilisation of stem cells.

Intracoronary delivery. In this approach, cells are infused inside the coronary artery, and this is generally done during brief coronary occlusion caused by inflating a balloon at the tip of the catheter (35-37). The advantages of this procedure include the uniform distribution of injected cells in the infarcted region, relative simplicity of the technique without the need for specialized equipment. The procedure is practical for widespread utilization in clinical practice. However, intracoronary delivery has some disadvantages. Indeed, with this approach, the immediate retention of cells is low, there is a possibility of microvascular occlusion due to large cells, and the cell delivery to a myocardial region supplied by an occluded artery is impossible (35-37).

Intravenous infusion. It has been shown that the intravenous delivery of EPCs (38) or MSCs (39) improves cardiac function in animal models following AMI, while the homing of cells to non-cardiac organs limits the clinical application of this approach. Indeed, the myocardial homing of BMMNCs was found important only following intracoronary stop-flow delivery, but not after intravenous injection in patients with post-AMI (40).

Mobilization of stem cells. Given that the infarcted myocardium attracts circulating stem cells to the site of injury, the mobilization of stem cells by cytokines may provide a noninvasive approach for cardiac regeneration. This possibility was tested preclinically in animal models of AMI (41) and clinically in patients with AMI and chronic myocardial ischemia (42).

Direct injection into the ventricular wall. The direct injection of cells into the ventricular wall is considered as a favored method for cell delivery when an occluded coronary artery precludes transvascular cell delivery or when cell homing signals are expressed at low levels in the heart. However, the direct injection of cells into the ischemic or scarred myocardium creates islands of cells with limited blood supply. This may lead to poor cell survival. Different approaches of direct injection are particularly appropriate for the application of large cells, such as MSCs or SMs that may cause microembolization following intracoronary delivery. These approaches have been used in patients with advanced coronary artery disease or ischemic cardiomyopathy, but may be technically challenging in patients with AMI, particularly if cells have to be injected into the border zone of the infarct. The safety of such an approach should be investigated, as the perforation of the friable necrotic tissue is a matter of concern. In general, direct injection can be performed by transendocardial, transepicardial, or transcoronary delivery (43).

Transepicardial injection. Transepicardial injection is performed as an adjunct to CABG during cardiac surgery. The procedure permits the direct visualization of the myocardium and the targeted application of cells to scarred areas and the border zone of an infarct scar. However, the efficiency of cell transplantation may be difficult to evaluate and determine if CABG is performed simultaneously (44).

Transendocardial injection. In this approach, cells are delivered directly inside the LV with an injection catheter advanced across the aortic valve and positioned against the endocardial surface. Advantageously, electromechanical mapping of the endocardial surface with a catheter-based nonfluoroscopic three-dimensional (NOGA) system (45) can be used to monitor ischemic and scarred but viable myocardium, thereby facilitating targeted injection of cells into the scar or into the border zone. In addition, cells can be distributed in a scarred region, even in the presence of a total occlusion of the coronary artery supply (15). Given these advantages, cell injection by transendocardial approach has been largely performed in the clinical setting (46). However, it is important to note that an intramyocardial injection can disrupt tissue architecture and generate cell clumps that eventually die from a lack of adequate blood supply. Furthermore, cells are always heterogeneously distributed in the infarct zone.

Transcoronary vein injection. The procedure requires a catheter system incorporating an ultrasound tip for guidance and an extendable needle for myocardial access. With such a system, cells are delivered parallel to the ventricular wall and deep into the injured myocardium (47).

\section{Potential therapeutic mechanisms of stem cells}

Stem cells have been reported to initiate myocardial repair and improve cardiac function through direct and indirect mechanisms, including differentiation into cardiac and vascular cells, paracrine effects and cell fusion (Fig. 2).

Differentiation of transplanted stem cells into cardiac cells. The differentiation of injected stem cells into cardiomyocytes is one of the major controversies in the field of cardiac regeneration. Indeed, although differentiation may provide the clearest explanation for the therapeutic effect of transplanted stem cells, there is no clear evidence supporting this. While certain studies using genetic and fluorescent labeling support the differentiation as important mechanism for cardiac regeneration (2,48-50), other studies challenge this notion despite improved LV function $(8,48)$. Accordingly, the majority of stem cell-based therapies have reported improvement of both LV function and vascular remodeling, without necessarily forming new cardiomyocytes.

Formation of new blood vessels from transplanted stem cells. Various cell types have demonstrated the ability to differentiate into new blood vessels following their transplantation. This phenomenon is likely essential for models of chronic coronary occlusion with ischemic but viable myocardium, 


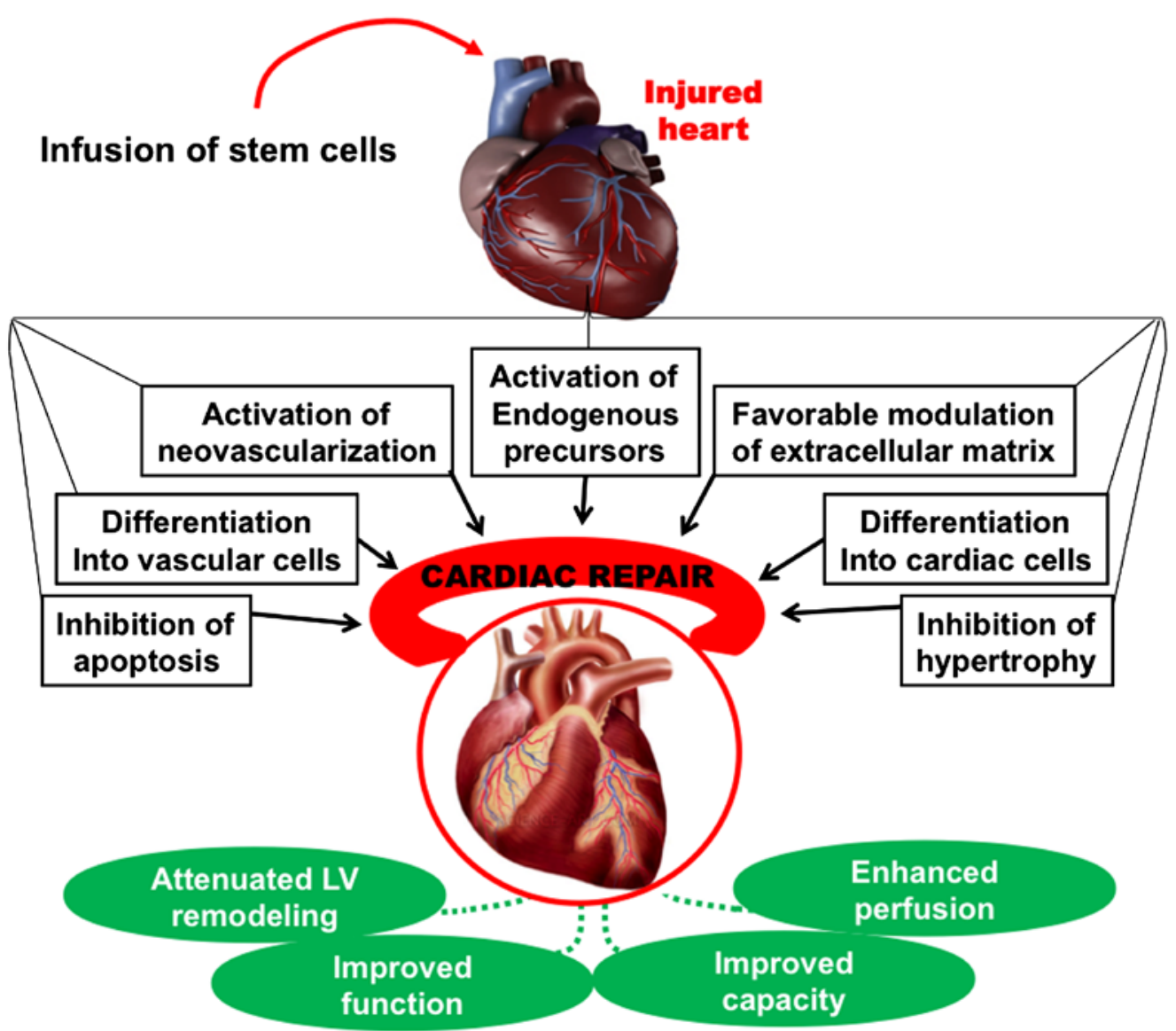

Figure 2. Potential therapeutic mechanisms of stem cells. Infusion of stem cells in the injured heart initiates myocardial repair via several direct and indirect mechanisms, including differentiation into cardiac and vascular cells, cell fusion and paracrine effects such as activation of endogenous precursors, promotion of neovascularisation, favorable modulation of the extracellular matrix, inhibition of apoptosis, and inhibition of hypertrophy. Collectively, these events result in enhanced LV function, improved perfusion, and improved cardiac function, leading to improvement in clinical status.

however, not for models with infarcted and scarred myocardium (49). Interestingly, patients with ischemic heart disease have demonstrated improved cardiac performance, which was associated with formation of new vessels from transplanted stem cells (50). This is indicative of the clinical importance of stem cell differentiation in patients suffering from ischemic cardiomyopathy. It is however, difficult to envisage the process in the setting of non-ischemic cardiomyopathy or in patients suffering from ischemic heart disease but without flowlimiting coronary lesions.

Paracrine effect. Paracrine effect is a concept that has been proposed to provide an explication regarding the therapeutic effects of transplanted stem cells on injury tissues. It refers to the notion that transplanted stem cells repair damaged myocardium by releasing into the surrounding tissue, several factors such as cytokines, chemokines, growth factors, exosomes or microparticles, which initiate various processes of restoration that include activation of endogenous CSCs, neovascularisation (51), inhibition of apoptosis, inhibition of hypertrophy, and favorable alterations of the extracellular matrix.

Cell fusion. Cell fusion refers to a cellular mechanism in which many mononuclear cells combine to form a syncytium. A study examining cell fusion events of BMMNCs with cardiomyocytes using a procedure based on Cre-lox recombination, has indicated that cell fusion is the alternative mechanism used by transplanted BMMNCs to generate different adult tissues (4). However, subsequent studies concluded that cell fusion is not required for the differentiation of BMMNCs into cardiomyocytes and coronary vessels (52). Furthermore, the Cre-lox recombination-based method appears inappropriate to study cell fusion, since unmodified Cre-recombinase in stem cells can imitate cell fusion by crossing the cell membrane. Consequently, the importance of cell fusion in therapeutic mechanisms of the stem cell seems stripped of support.

\section{Conclusion}

Despite considerable resources and effort dedicated over the last decade to study the bioactivity of stem cells and examine their potentiality for clinical intervention, stem cell therapy for cardiovascular disease remains a relatively young science. Nevertheless, remarkable progress has been made in a relatively short time during which, most of clinical trials conducted were generally small and inconclusive. However, the results were encouraging, and the stem cell therapy appears safe. This therapeutic approach is likely a clinical reality that may revolutionize the treatment of cardiovascular disease. 


\section{References}

1. Zannad F, Agrinier N and Alla F: Heart failure burden and therapy. Europace 11 (Suppl 5): v1-v9, 2009.

2. Orlic D, Kajstura J, Chimenti S, Jakoniuk I, Anderson SM, Li B, Pickel J, McKay R, Nadal-Ginard B, Bodine DM, et al: Bone marrow cells regenerate infarcted myocardium. Nature 410 701-705, 2001

3. Taylor DA, Atkins BZ, Hungspreugs P, Jones TR, Reedy MC, Hutcheson KA, Glower DD and Kraus WE: Regenerating functional myocardium: improved performance after skeletal myoblast transplantation. Nat Med 4: 929-933, 1998.

4. Murry CE, Wiseman RW, Schwartz SM and Hauschka SD: Skeletal myoblast transplantation for repair of myocardial necrosis. J Clin Invest 98: 2512-2523, 1996.

5. Pagani FD, DerSimonian H, Zawadzka A, Wetzel K, Edge AS Jacoby DB, Dinsmore JH, Wright S, Aretz TH, Eisen HJ and Aaronson KD: Autologous skeletal myoblasts transplanted to ischemia-damaged myocardium in humans. Histological analysis of cell survival and differentiation. J Am Coll Cardiol 41: 879-888, 2003.

6. Menasché $\mathrm{P}$, Hagège $\mathrm{A} A$, Scorsin $\mathrm{M}$, Pouzet $\mathrm{B}$, Desnos $\mathrm{M}$, Duboc D, Schwartz K, Vilquin JT and Marolleau JP: Myoblast transplantation for heart failure. Lancet 357: 279-280, 2001

7. Menasché $\mathrm{P}$, Hagège AA, Vilquin JT, Desnos M, Abergel E, Pouzet B, Bel A, Sarateanu S, Scorsin M, Schwartz K, et al: Autologous skeletal myoblast transplantation for severe postinfarction left ventricular dysfunction. J Am Coll Cardiol 41: 1078-1083, 2003

8. Murry CE, Soonpaa MH, Reinecke H, Nakajima H, Nakajima HO, Rubart M, Pasumarthi KB, Virag JI, Bartelmez SH, Poppa V, et al: Haematopoietic stem cells do not transdifferentiate into cardiac myocytes in myocardial infarcts. Nature 428: 664-668, 2004.

9. Strauer BE, Brehm M, Zeus T, Köstering M, Hernandez A, Sorg RV, Kögler G and Wernet P: Repair of infarcted myocardium by autologous intracoronary mononuclear bone marrow cell transplantation in humans. Circulation 106: 1913-1918, 2002

10. Traverse JH, Henry TD, Pepine CJ, Willerson JT, Zhao DX, Ellis SG, Forder JR, Anderson RD, Hatzopoulos AK, Penn MS et al; Cardiovascular Cell Therapy Research Network (CCTRN): Effect of the use and timing of bone marrow mononuclear cell delivery on left ventricular function after acute myocardial infarction: the TIME randomized trial. JAMA 308: 2380-2389, 2012.

11. Sürder D, Schwitter J, Moccetti T, Astori G, Rufibach K, Plein S, Lo Cicero V, Soncin S, Windecker S, Moschovitis A, et al: Cell-based therapy for myocardial repair in patients with acute myocardial infarction: rationale and study design of the SWiss multicenter Intracoronary Stem cells Study in Acute Myocardial Infarction (SWISS-AMI). Am Heart J 160: 58-64, 2010.

12. Traverse JH, Henry TD, Ellis SG, Pepine CJ, Willerson JT, Zhao DX, Forder JR, Byrne BJ, Hatzopoulos AK, Penn MS, et al; Cardiovascular Cell Therapy Research Network: Effect of intracoronary delivery of autologous bone marrow mononuclear cells 2 to 3 weeks following acute myocardial infarction on left ventricular function: the LateTIME randomized trial. JAMA 306: 2110-2119, 2011

13. Davani S, Marandin A, Mersin N, Royer B, Kantelip B, Hervé P, Etievent JP and Kantelip JP: Mesenchymal progenitor cells differentiate into an endothelial phenotype, enhance vascular density, and improve heart function in a rat cellular cardiomyoplasty model. Circulation 108 (Suppl 1): II253-II258, 2003.

14. Chen SL, Fang WW, Ye F, Liu YH, Qian J, Shan SJ, Zhang JJ, Chunhua RZ, Liao LM, Lin S and Sun JP: Effect on left ventricular function of intracoronary transplantation of autologous bone marrow mesenchymal stem cell in patients with acute myocardial infarction. Am J Cardiol 94: 92-95, 2004.

15. Hare JM, Fishman JE, Gerstenblith G, DiFede Velazquez DL, Zambrano JP, Suncion VY, Tracy M, Ghersin E, Johnston PV, Brinker JA, et al: Comparison of allogeneic vs autologous bone marrow-derived mesenchymal stem cells delivered by transendocardial injection in patients with ischemic cardiomyopathy: the POSEIDON randomized trial. JAMA 308: 2369-2379, 2012.

16. Manginas A, Goussetis E, Koutelou M, Karatasakis G,Peristeri I, Theodorakos A, Leontiadis E, Plessas N, Theodosaki M, Graphakos S, et al: Pilot study to evaluate the safety and feasibility of intracoronary CD133(+) and CD133(-) CD34(+) cell therapy in patients with nonviable anterior myocardial infarction. Catheter Cardiovasc Interv 69: 773-781, 2007.
17. Patel AN, Geffner L, Vina RF, Saslavsky J, Urschel HC Jr, Kormos R and Benetti F: Surgical treatment for congestive heart failure with autologous adult stem cell transplantation: aprospective randomized study. J Thorac Cardiovasc Surg 130: 1631-1638, 2005.

18. Stamm C, Kleine HD, Choi YH, Dunkelmann S, Lauffs JA, Lorenzen B, David A, Liebold A, Nienaber C, Zurakowski D, et al: Intramyocardial delivery of $\mathrm{CD} 133^{+}$bone marrow cells and coronary artery bypass grafting for chronic ischemic heart disease: safety and efficacy studies. J Thorac Cardiovasc Surg 133: 717-725, 2007.

19. Perin EC, Silva GV, Zheng Y, Gahremanpour A, Canales J, Patel D, Fernandes MR, Keller LH, Quan X, Coulter SA, et al: Randomized, double-blind pilot study of transendocardial injection of autologous aldehyde dehydrogenase-bright stem cells in patients with ischemic heart failure. Am Heart J 163: 415-421, 421.e1, 2012.

20. Miyahara Y, Nagaya N, Kataoka M, Yanagawa B, Tanaka K, Hao H, Ishino K, Ishida H, Shimizu T, Kangawa K, et al: Monolayered mesenchymal stem cells repair scarred myocardium after myocardial infarction. Nat Med 12: 459-465, 2006.

21. Mazo M, Planat-Bénard V, Abizanda G, Pelacho B, Léobon B, Gavira JJ, Peñuelas I, Cemborain A, Pénicaud L, Laharrague P, et al: Transplantation of adipose derived stromal cells is associated with functional improvement in a rat model of chronic myocardial infarction. Eur J Heart Fail 10: 454-462, 2008.

22. Linke A, Müller P, Nurzynska D, Casarsa C, Torella D, Nascimbene A, Castaldo C, Cascapera S, Böhm M, Quaini F, et al: Stem cells in the dog heart are self-renewing, clonogenic, and multipotent and regenerate infarcted myocardium, improving cardiac function. Proc Natl Acad Sci USA 102: 8966-8971, 2005.

23. Fischer KM, Cottage CT, Wu W, Din S, Gude NA, Avitabile D, Quijada P, Collins BL, Fransioli $J$ and Sussman MA: Enhancement of myocardial regeneration through genetic engineering of cardiac progenitor cells expressing Pim-1 kinase. Circulation 120: 2077-2087, 2009.

24. Angert D, Berretta RM, Kubo H, Zhang H, Chen X, Wang W, Ogorek B, Barbe M and Houser SR: Repair of the injured adult heart involves new myocytes potentially derived from resident cardiac stem cells. Circ Res 108: 1226-1237, 2011.

25. Bolli R, Chugh AR, D'Amario D, Loughran JH, Stoddard MF, Ikram S, Beache GM, Wagner SG, Leri A, Hosoda T, et al: Cardiac stem cells in patients with ischaemic cardiomyopathy (SCIPIO): initial results of a randomised phase 1 trial. Lancet 378: 1847-1857, 2011.

26. Makkar RR, Smith RR, Cheng K, Malliaras K, Thomson LE, Berman D, Czer LS, Marbán L, Mendizabal A, Johnston PV, et al: Intracoronary cardiosphere-derived cells for heart regeneration after myocardial infarction (CADUCEUS): a prospective, randomised phase 1 trial. Lancet 379: 895-904, 2012.

27. Smith RR, Marban E and Marban L: Enhancing retention and efficacy of cardiosphere-derived cells administered after myocardial infarction using a hyaluronan-gelatin hydrogel. Biomatter 3: e24490, 2013.

28. Bonios M, Chang CY, Pinheiro A, Dimaano VL, Higuchi T, Melexopoulou C, Bengel F, Terrovitis J, Abraham TP and Abraham MR: Cardiac resynchronization by cardiospherederived stem cell transplantation in an experimental model of myocardial infarction. J Am Soc Echocardiogr 24: 808-814, 2011.

29. Oh H, Bradfute SB, Gallardo TD, Nakamura T, Gaussin V, Mishina Y, Pocius J, Michael LH, Behringer RR, Garry DJ, et al: Cardiac progenitor cells from adult myocardium: homing, differentiation, and fusion after infarction. Proc Natl Acad Sci USA 100: 12313-12318, 2003.

30. Kehat I, Khimovich L, Caspi O, Gepstein A, Shofti R, Arbel G, Huber I, Satin J, Itskovitz-Eldor J and Gepstein L: Electromechanical integration of cardiomyocytes derived from human embryonic stem cells. Nat Biotechnol 22: 1282-1289, 2004.

31. Min JY, Yang Y, Converso KL, Liu L, Huang Q, Morgan JP and Xiao YF: Transplantation of embryonic stem cells improves cardiac function in postinfarcted rats. J Appl Physiol (1985) 92: 288-296, 2002.

32. Takahashi K, Tanabe K, Ohnuki M, Narita M, Ichisaka T, Tomoda $\mathrm{K}$ and Yamanaka S: Induction of pluripotent stem cells from adult human fibroblasts by defined factors. Cell 131: 861-872, 2007.

33. Takahashi $\mathrm{K}$ and Yamanaka S: Induction of pluripotent stem cells from mouse embryonic and adult fibroblast cultures by defined factors. Cell 126: 663-676, 2006. 
34. Ma T, Xie M, Laurent T and Ding S: Progress in the reprogramming of somatic cells. Circ Res 112: 562-574, 2013.

35. Strauer BE, Brehm M, Zeus T, Gattermann N, Hernandez A, Sorg RV, Kogler G and Wernet P: [Intracoronary, human autologous stem cell transplantation for myocardial regeneration following myocardial infarction]. Dtsch Med Wochenschr 126: 932-938, 2001.

36. Bui QT, Gertz ZM and Wilensky RL: Intracoronary delivery of bone-marrow-derived stem cells. Stem Cell Res Ther 1: 29, 2010.

37. Wojakowski W, Tendera M, Cybulski W, Zuba-Surma EK, Szade K, Florczyk U, Kozakowska M, Szymula A, Krzych L, Paslawska U, Paslawski R, Milewski K, Buszman PP, Nabialek E, Kuczmik W, Janiszewski A, Dziegiel P, Buszman PE, Jozkowicz A and Dulak J: Effects of intracoronary delivery of allogenic bone marrow-derived stem cells expressing heme oxygenase-1 on myocardial reperfusion injury. Thromb Haemost 108: 464-475, 2012.

38. Kawamoto A, Gwon HC, Iwaguro H, Yamaguchi JI, Uchida S, Masuda H, Silver M, Ma H, Kearney M, Isner JM and Asahara T: Therapeutic potential of ex vivo expanded endothelial progenitor cells for myocardial ischemia. Circulation 103: 634-637, 2001

39. Pittenger MF and Martin BJ: Mesenchymal stem cells and their potential as cardiac therapeutics. Circ Res 95: 9-20, 2004

40. Hofmann M, Wollert KC, Meyer GP, Menke A, Arseniev L, Hertenstein B, Ganser A, Knapp WH and Drexler H: Monitoring of bone marrow cell homing into the infarcted human myocardium. Circulation 111: 2198-2202, 2005.

41. Norol F, Merlet P, Isnard R, Sebillon P, Bonnet N, Cailliot C, Carrion C, Ribeiro M, Charlotte F, Pradeau P, et al: Influence of mobilized stem cells on myocardial infarct repair in a nonhuman primate model. Blood 102: 4361-4368, 2003

42. Powell TM, Paul JD, Hill JM, Thompson M, Benjamin M, Rodrigo M, McCoy JP, Read EJ, Khuu HM, Leitman SF, et al Granulocyte colony-stimulating factor mobilizes functional endothelial progenitor cells in patients with coronary artery disease. Arterioscler Thromb Vasc Biol 25: 296-301, 2005.

43. Archundia A, Aceves JL, Lopez-Hernandez M, Alvarado M Rodriguez E, Diaz QG, Paez A, Rojas FM and Montano LF: Direct cardiac injection of G-CSF mobilized bone-marrow stemcells improves ventricular function in old myocardial infarction. Life Sci 78: 279-283, 2005.
44. Laham RJ, Post M, Rezaee M, Donnell-Fink L, Wykrzykowska JJ, Lee SU, Baim DS and Sellke FW: Transendocardial and transepicardial intramyocardial fibroblast growth factor-2 administration: Myocardial and tissue distribution. Drug Metab Dispos 33: 1101-1107, 2005.

45. Klemm HU, Franzen O, Ventura R and Willems S: Catheter based simultaneous mapping of cardiac activation and motion: a review. Indian Pacing Electrophysiol J 7: 148-159, 2007.

46. Perin EC, Silva GV, Henry TD, Cabreira-Hansen MG, Moore WH, Coulter SA, Herlihy JP, Fernandes MR, Cheong BY, Flamm SD, Traverse JH, Zheng Y, Smith D, Shaw S, Westbrook L, Olson R, Patel D, Gahremanpour A, Canales J, Vaughn WK and Willerson JT: A randomized study of transendocardial injection of autologous bone marrow mononuclear cells and cell function analysis in ischemic heart failure (FOCUS-HF). Am Heart J 161: 1078-1087, 2011.

47. Wu K, Mo X, Lu S and Han Z: Retrograde delivery of stem cells: Promising delivery strategy for myocardial regenerative therapy. Clin Transplant 25: 830-833, 2011 .

48. Limbourg FP, Ringes-Lichtenberg S, Schaefer A, Jacoby C, Mehraein Y, Jäger MD, Limbourg A, Fuchs M, Klein G, Ballmaier M, et al: Haematopoietic stem cells improve cardiac function after infarction without permanent cardiac engraftment. Eur J Heart Fail 7: 722-729, 2005.

49. Leri A, Kajstura J and Anversa P: Cardiac stem cells and mechanisms of myocardial regeneration. Physiol Rev 85: 1373-1416, 2005.

50. Humar R, de Miguel LS, Kiefer FN and Battegay EJ: Formation of new blood vessels in the heart can be studied in cell cultures. ALTEX Spec No 24: 35-38, 2007.

51. Kinnaird T, Stabile E, Burnett MS, Lee CW, Barr S, Fuchs S and Epstein SE: Marrow-derived stromal cells express genes encoding a broad spectrum of arteriogenic cytokines and promote in vitro and in vivo arteriogenesis through paracrine mechanisms. Circ Res 94: 678-685, 2004.

52. Kajstura J, Rota M, Whang B, Cascapera S, Hosoda T, Bearzi C, Nurzynska D, Kasahara H,Zias E, Bonafé M, et al: Bone marrow cells differentiate in cardiac cell lineages after infarction independently of cell fusion. Circ Res 96: 127-137, 2005. 